\title{
MULTIDIMENSIONAL CHARACTERISTICS OF TEACHER'S PROFESSIONAL COMPETENCE- CHALLENGE AND PERSPECTIVES DURING EDUCATION TRANSFORMATION PROCESS
}

\author{
Pāvels Jurs \\ University of Liepaja, Latvia \\ Inta Kulberga \\ University of Liepaja, Latvia
}

\begin{abstract}
The issue of teacher's professional competence is multidimensional and multifaceted, it depends on several aspects, including educational policy, system implemented in every country and the particular educational establishment, which the educator works for. Being aware of the current pedagogical reality, challenges of the education system, pupils' needs and manifold learning and teaching strategies, educators need knowledge, skills and experience of different levels formed for each particular individual in combination of education and experience with their physical, psychological and mental abilities. The goal of the article is to identify the structure of teacher's professional competence being conscious of the theoretical and normative framework on the international and national level. In the article the theoretical research methods (method of comparison and critical thinking) and empirical research methods (data collection and document analysis) have been applied. In the society, educational institutions, also being aware of the transformation process in the education content and branch, there is a demand for teachers with a high level of professional competence. Education policy makers have set a very broad and extensive professional competence standard, which includes in itself both aspects related to the professional activity and individual characteristics, features and values. At the same time, there are various theoretical approaches which describe the framework of teacher's professional competence and its multidimensional characteristic. The authors of the article have identified general knowledge, skills and attitude, as well as pedagogical knowledge, skills and attitude in the framework of the teacher's professional competence structure.
\end{abstract}

Keywords: education, professional competence, school, teacher.

\section{Introduction}

Being aware of the current pedagogical reality, challenges of the education system, pupils' needs and manifold teaching and learning strategies, educators need knowledge, skills and experience of different levels formed for every particular individual in combination of education and experience with their physical, psychological and mental abilities. Therefore, the framework of 
teacher's professional competence becomes topical. The goal of the article is to identify the structure of teacher's professional competence being conscious of the theoretical and normative framework on the international and national level. In the article the theoretical research methods (method of comparison and critical thinking) and empirical research methods (data collection and document analysis) have been applied (Martinsone, Pipere, \& Kamerāde, 2016).

Initially the concept of competence was broadly applied mostly in the colloquial speech in relation to the individual's readiness for professional activity. The professional competence as a concept was introduced in the 1960s when D. McClelland (McClelland, 1973) described human knowledge, skills and attitudes which appear in a specific behaviour, personalities, values and disposition of motives performing some kind of work or a role. Up to the 90s of the $20^{\text {th }}$ century they mainly talked about the necessary competence or qualifications for a professional activity performance as synonyms. However, in the late 90s the separation between qualification and competence was started, thus starting to develop an explanation that directly characterizes professional competence. As a result, the individual's corresponding special knowledge, skills and abilities have been separated, which are obtained through learning and applying experience from the individual's general knowledge and skills (King, King, \& Rothwell, 2001, Henschel, 2001, Dubois \& Rothwell, 2004).

\section{Description of Teacher's Professional Competence}

The issue of teacher's professional competence is multidimensional and multifaceted, it depends on several aspects, including education policy, the system implemented in every country and the particular educational establishment which the educator works for. In a broader context the educator's professional competence is described by: learning opportunities, application of learning opportunities; confidence; motivation; self-regulation; pedagogical experience; legislation; cooperation skills; support; personality traits; character; cognitive abilities; pupils' learning outcomes; ability for find innovative pedagogical solutions; positive self-esteem in the workplace (Kunter, Kleickmann, Klusmann, \& Richter, 2013), as well as: professional knowledge - knowledge on educational content (Loughran, Berry, \& Mulhall, 2012); masterful application of pedagogical approaches and pupils, parents' feedback (Guerriero \& Révai, 2017); understanding of globalization and multicultural competence (Orazbayeva, 2016); digital competence (Caena \& Redecker, 2019); conflict and problem-solving (Toom, 2017); creativity- it teaches thinking (De Bono, 2009); responsibility to oneself, pupils, parents, colleagues, school, city and the state (Lauermann, 2017). The educator's professional competence is also closely related to the educator's personality, whereas the concept of personality is a very multifaceted and 
monumental formation, which derives from the heredity, environment, upbringing, situation and experience obtained during the lifetime (Karpova, 2005). The most typical personality traits derive from the individually psychological dimension and general individual peculiarities (Strika, 2009), skills and attitude (Parsons, 2011), as well as talent or systematically developed individual's innate abilities (Nijs, Gallardo-Gallardo, Dries, \& Sels, 2014). As the co-authors of the new Latvia Education Content Based on Competence emphasise in the monograph "Mācī̌anās lietpratībai" ("Learning for Proficiency") (2018), then: "the educator's competence consists of knowledge, skills and beliefs that have resulted in the action. The educator has to be able to: (I) set relevant learning goals for the pupil and give useful feedback on their achievement, teach pupils to formulate the goal themselves, follow the progress towards it, provide and receive the feedback - promote a self-directed learning; (II) select and apply skilfully learning techniques, methods which achieve the pupil's probing and involvement, use productive assignments, create a link with the real life; (III) teach to apply purposefully the information and communication technology tools (Namsone, Volkinšteine, \& Lāce, 2018, p.155).

As the structure of the work environment changes, intellectual work develops more and more and being aware of the demand for the quality of education, it is no longer possible to single out only one specific understanding and explanation of the concept of competence, for the educator, while carrying out their work responsibilities, has to apply such abilities and skills (even multiple sets of competences) which are relevant and more appropriate for other situations in human life. In general, if the competence approach is applied to fulfil the educator's responsibilities, it is also possible to apply such a competence approach which combines components of the general (the desirable behaviour which is expected form all employees), functional (necessary depending on the functionality of the position) and specific (complying with the specifics of the educational institution) competences. Also, it is possible to form the competence hierarchy (Ennis, 2008), distinguishing between different levels of competence: (I) personal qualities of a person; (II) competence which is related to knowledge and skills acquisition in the academic and professional (work) environment; (III) competence of specific knowledge and skills in a specific field of activity of an educational institution (in measurement and technologies);(IV) within the framework of professions and particular position (professional - specific knowledge, technical knowledge and skills, management competence). Moreover, it should be mentioned that every individual has a chance to have a combination of their individual abilities, experience and opinions, which may include different, incl. general competence of person's individual experience and also structural elements obtained during their life activity. In their individual experience the personality develops their emotional, physical and social abilities, 
but during their life activity knowledge and skills are developed, which are obtained during both the self-experience and communication with other people. This is how the world experience is formed. According to what was said above, the competence existing in the competence model can be divided into different main groups which can be formed in a multilateral way (Fig.1).

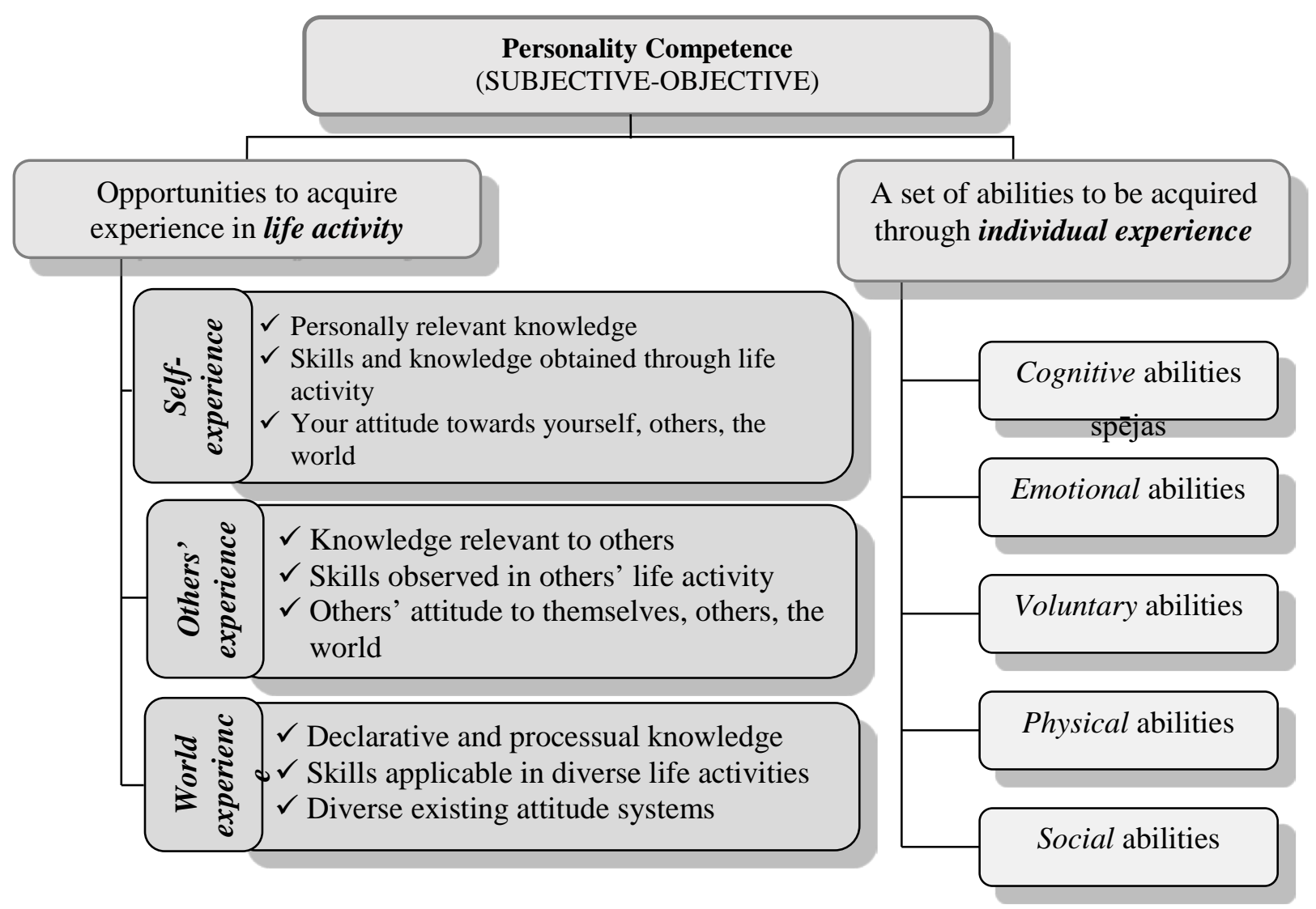

Figure1 Elements Forming Individual Competence of a Personality (Kulberga, 2013, p.52)

It should be noted that every educator is able to form their own individual model of competence for their professional activity provision and development, on the basis of which training can be planned for both personal development and improvement of professional skills. Attributing competence to a particular subject, it is related to the activity for the achievement of personally important goals and to the quality of the respective activity. In such a context one can talk about every human's individual potential or unique abilities obtained and justified in experience, which can be considered as personality competence.

\section{Description of Teacher's Professional Competence - Latvia Experience}

In the informative report of the Ministry of Education and Science of the Republic of Latvia (January 9, 2018) "Proposals for the Provision of Conceptually 
New Competency-based Teacher Education in Latvia” it is mentioned that outstanding educators are characterized by such important values for the society as openness, cooperation, leadership, honesty, the state will and respect (Latvijas Republikas Ministru kabineta tiesību aktu projekti, 2018). On May 25, 2018 in the meeting of the Tripartite Cooperation Sub-Council for Vocational Education and Employment the professional standard "Teacher," developed by the National Centre for Education, was approved, which envisages the following responsibilities and tasks of the educator: (I) planning of the study process; (II) implementation of the study process; (III) assessment of the pupil's learning achievement and growth; (IV) development of their professional competence; (V) participation in the development of the educational institution and education field. In the context alongside the educator's responsibilities and tasks the professional standard envisages that the educator must have a certain competence which is orientated towards the implementation of the educator's basic responsibility - the educator directs purposefully the development of the pupil's competence according to the pupil's individual needs for their development, learning, personality and social growth (Valsts Izglìtības satura centrs, 2018).

In the professional standard general educator's competences, required for professional activity performance , are mentioned: (1) apply information and communication technologies; (2) act in compliance with the law; (3) communicate in the state language and at least in one of the European Union's official languages; (4) take care of their physical, intellectual, emotional health; (5) comply with the requirements of the labour law, labour protection and environmental protection; (6) assess their work ability and health condition at the workplace and during the performance of work duties; (7) in case of an accident, act appropriately and provide first aid to the injured.

When analysing the educator's professional standard, several essential aspects should be mentioned:

1. professional standard has been described, structured in a great detail and it complies with the pedagogical environment and reflects the educator's multifaceted and complicated daily life;

2. defined duties of the educator allow to reduce the possible interpretations of the teacher's daily duties and field of responsibility;

3. standard of the educator's profession most directly promotes the quality of education, provides an individualized approach to the pupil and defines the competence of the educator's profession;

4. based on the professional standard, higher educational institutions can organize more purposefully the teachers' training, adapting the content of the study courses in compliance with the requirements; 
5. based on the teacher's professional standard, a unified educators' work assessment system on the national scale can be developed, thus unifying diagnostics of the educators' professional competence;

6. based on the teacher's professional standard, the procedure for accreditation of general and vocational education institutions may be improved.
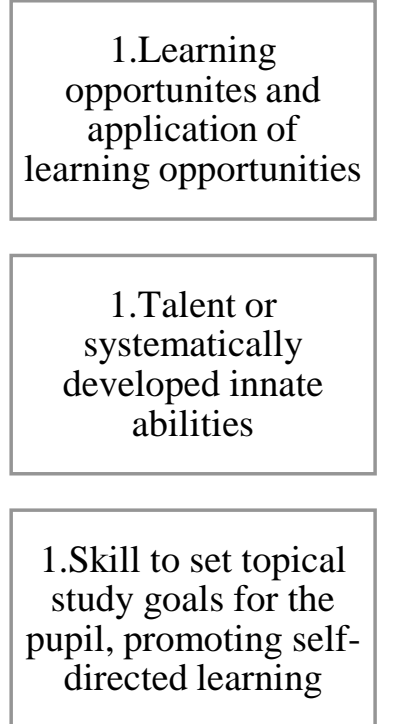

1.Formation of pupils' competence, selecting the most suitable learning and teaching strategies

\section{Constant and purposeful development of pedagogical professionalism}

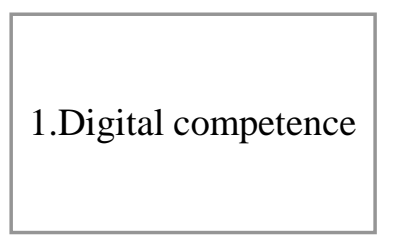

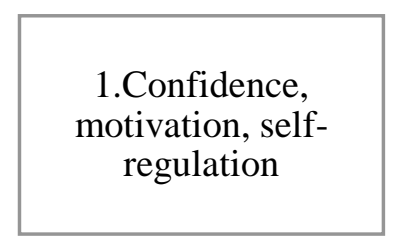

1.Responsibility for themselves, pupils, parents, colleagues, school, city and the state

1.Development dynamics of pupils' individual learning and diagnostics of

learning needs

1.Systematic and purposeful

application of the feedback

1.Strategic planning, implementation and assessment of pedagogical work

1.Conflict and problem solving

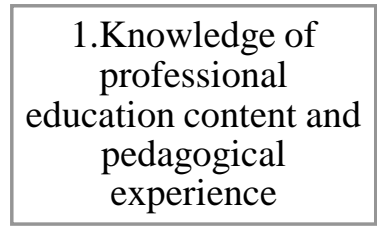

1.Pupils' learning achievements and outcomes
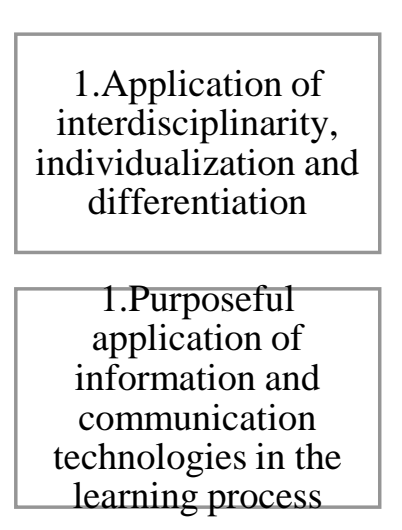

1.Understanding of globalization and multicultural competence
1.Participation in the eductional institution's development

1.Personality traits, character and cognitive abilities

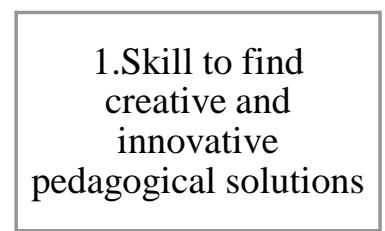

1.Holistic assessment of the learning process, applying efficiently available resources

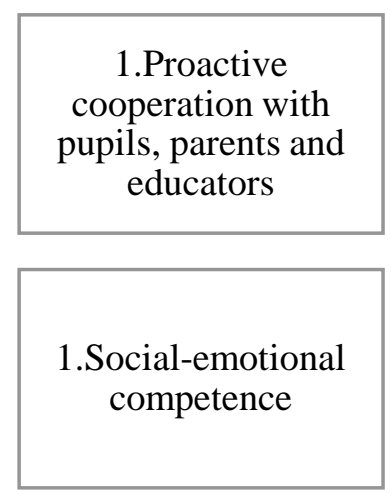

1.Knowledge and understanding of education field legislation and other topicalities

Figure 2 Framework of Teacher's Professional Competence Structure

Based on the educator's professional standard analysed above, as well as being aware of the diverse characteristics of the educator's professional competence, which has been described in the publication, the authors of the article 
bring forward for discussion the following framework of the teacher's professional competence structure (Fig. 2).

Analysis of the regulatory framework of the Republic of Latvia and the new concept of educational content, based on theoretical research and aware of the educational trends of the 21 st century, authors of article put forward for further research and discussion the framework of the teacher's professional competence structure (Fig. 2). Proposed structure highlights the multidimensional nature of teacher's professional competence and the interrelationship between the components of the framework is formed by professional characteristics, personality specialities and the professional competence of the teacher's, which can contribute positively to the teaching and learning process.

\section{Conclusions}

1. In the society, educational institutions, as well as being aware of the transformation processes in the education content and field, there is a demand for teachers with a high level of professional competence. Education policy makers, parents, the pupil and society have set a very broad and extensive teacher's professional competence standard, which includes in itself both aspects related to the professional activity and individual characteristics, qualities and values.

2. There are diverse theoretical approaches which describe the framework of the teacher's professional competence and its multidimensional features. Therefore, the content adaptation of the trainee teachers' training programmes and educators' professional competence development programmes to the new requirements, in compliance with the prevailing demand for the teacher's professional competence quality, becomes really topical.

3. As general knowledge, skills and attitude within the framework of the teacher's professional competence structure, the following components can be distinguished: (I) learning opportunities and application of learning opportunities; (II) confidence, motivation, self-regulation; (III) personality traits, character and cognitive abilities; (IV) talent or systematically developed individual's innate abilities; (V) responsibility to yourself, pupils, parents, colleagues, school, city and the state; (VI) skill to find creative and innovative solutions; (VII) understanding of globalization and multicultural competence; (VIII) social-emotional competence; (IX) digital competence; (X) conflict and problem solving; (XI) participation in the educational institution's development; (XII) knowledge and understanding of education field legislation. 
4. As pedagogical knowledge, skills and attitude within the framework of the teacher's professional competence structure, the following components can be distinguished: (I) knowledge of the professional education content and pedagogical experience; (II) pupils' learning success and outcomes; (III) ability to set topical learning goals for the pupil, promoting self-directed learning; (IV) diagnostics of pupils' individual learning development dynamics and learning needs; (V) application of balanced approaches to interdisciplinarity, individualization, differentiation, evaluation and methodological methods; (VI) holistic approach of the learning process, applying efficiently the available resources; (VII) formation and development of pupils' competence, selecting the most appropriate learning and teaching strategies; (VIII) systematic and purposeful application of the feedback; (IX) purposeful application of information and communication technologies in the learning process; $(\mathrm{X})$ proactive cooperation with pupils, parents and educators; (XI) strategic planning, implementation and assessment of pedagogical work; (XII) constant development of pedagogical professionalism.

\section{References}

Caena, F., Redecker, C. (2019). Aligning teacher competence frameworks to 21st century challenges: The case for the European Digital Competence Framework for Educators (DigcompeDu). In G. Halász, J. Looney (Ed.), European Journal of Education, 54(3), 356-369. DOI: 10.1111/ejed.12345

De Bono, E. (2009). Lateral Thinking: A Textbook of Creativity. London: Penguin.

Dubois, D., Rothwell, W. (2004). Competency-Based Human Resource Management. Boston: Davies-Black Publishing.

Ennis, M. (2008). Competency Models: A Review of the Literature and The Role of the Employment and Training Administration (ETA). U.S. Department of Labor, Employment and Training Administration, Office of Policy Development and Research, Pilots and Demonstration Team.

Guerriero, S., Révai, N. (2017). Knowledge-based teaching and the evolution of a profession. In S. Guerriero (Ed.), Pedagogical Knowledge and the Changing Nature of the Teaching Profession (253-269). Paris: OECD Publishing. DOI: 10.1787/9789264270695-en

Henschel, T. (2001). Dialogische Handlungs - und Entscheidung - Kompetenzen, Welche Bildung brauchen wir für das Wissenszeitalter? In Lein, K-M. (Ed.), Orientierung für die Zukunft. Bildung im Wettbewerb (137-152). Frankfurt, Main: Piper.

Karpova, Ā. (2005). Personības psiholog̣iskie modeḷi izcilo pedagog̣iskās domas kopēju dzīves darbības atspogul,ojumos. In A. Krūze (Ed.), Laikmets un personība (9 - 40). Rīga: RaKa.

King, S., King, M., Rothwell, W. (2001). The complete guide to training delivery: A competency-based approach. New York: American Management Association.

Kulberga, I. (2013). Uzñēmējdarbības vadītāja profesionālās kompetences pilnveidošana Latvijā. Promocijas darbs. Rīga: Latvijas Universitātes Ekonomikas un vadības fakultāte. 
SOCIETY. INTEGRATION. EDUCATION

Proceedings of the International Scientific Conference. Volume II, May $28^{\text {th }}-29^{\text {th }}$, 2021. 244-252

Kunter, M., Kleickmann, T., Klusmann, U., Richter, D. (2013). The Development of Teachers' Professional Competence. In M. Kunter, J. Baumert, W. Blum, U, Klusmann, S. Krauss, M. Neubrand (Ed), Cognitive Activation in the Mathematics Classroom and Professional Competence of Teachers (63-77). Boston: Springer. DOI: 10.1007/978-1-4614-5149-5

Latvijas Republikas Ministru kabineta tiesību aktu projekti. (2018). Informatīvais ziñojums "Priekšlikumi konceptuāli jaunas kompetencēs balstītas izglìtības prasībām atbilstošas skolotāju izglītības nodrošināšanai Latvijā”. Rīga: Izglītības un zinātnes ministrija. Retrieved from http://tap.mk.gov.lv/mk/tap/?pid=40444622

Lauermann, F. (2017). Knowledge-based teaching and the evolution of a profession. In S.Guerriero (Ed.), Teacher motivation, responsibility, pedagogical knowledge and professionalism: a new era for research (171-191). Paris: OECD Publishing. DOI: 10.1787/9789264270695-en

Loughran, J., Berry, A., Mulhall, P. (2012). Understanding and Developing Science Teachers' Pedagogical Content Knowledge: 2nd Edition. Rotterdam: Sense Publisher.

Martinsone, K., Pipere, A., Kamerāde, D. (2016). Pētniecība: teorija un prakse. Rīga: RaKa.

McClelland, D. (1973). Testing for Competence Rather than for Intelligence. In A. Kazak (Ed.), American Psychologist 27(1), 1-14.

Namsone, D., Volkinšteine, J., Lāce, G. (2018). Skolotājam nepieciešamās kompetences. In D.Namsone (Ed.), Mācī̌šnās lietpratībai (146-157). Rīga: LU Akadēmiskais apgāds. DOI: $10.22364 / \mathrm{ml} .2018 .6$

Nijs, S., Gallardo-Gallardo, E., Dries, N., Sels, L. (2014). A multidisciplinary review into the definition, operationalization, and measurement of talent. In A. Gaur (Ed), Journal of World Business 49(2), 180-191. DOI: 10.1016/j.jwb.2013.11.002

Orazbayeva, K. (2016). Professional Competence of Teachers in the Age of Globalization. In International Journal of Environmental and Science Education, 11(9), 2659-2672. DOI: 10.12973/ijese.2016.714a

Parsons, R. (2011). Fundamentals of the Helping Process. 2nd Edition. Long Grove: Waveland Press.

Strika, E. (2009). Tiesu psihiatriskajā vai kompleksajā tiesu psihologiskajā un psihiatriskajā ekspertīzē nonākušo likumpārkāpēju personības raksturojums. Promocijas darba kopsavilkums. Rīga: Latvijas Universitātes Pedagoǵijas un psiholoǵijas fakultātes Psihologijas nodalia.

Toom, A. (2017). Teacher's professional and pedagogical competencies: A complex divide between teacher's work, teacher knowledge and teacher education. In D. Clandinin, J. Husu (Ed), The SAGE Handbook of Research on Teacher Education, 2, (803-819). London: Sage.

Valsts Izglītības satura centrs. (2018). Profesijas standarts "Skolotājs". Retrieved from https://registri.visc.gov.lv/profizglitiba/dokumenti/standarti/2017/PS-048.pdf 